\title{
Development of Augmented Reality for Biology E-Magazine
}

Deka Gusnia Putri*, Zulfarina, Wan Syafii

Magister of Biology Education, University of Riau, Pekanbaru, 28293, Indonesia.

\section{ARTICLE INFO}

\section{Article history:}

Received: 24 Feb 2021

Revised: 03 July 2021

Accepted: 05 July 2021

Published online: 24 July 2021

Keywords:

Augmented reality

e-magazine

\begin{abstract}
A B S T R A C T
The purpose of this research is to design an electronic magazine design so that students are interested in participating in the learning process. Many students find it difficult to understand biology concepts because they cannot see it directly. We can use Augmented Reality technology in e-magazine design as one of these innovations. Therefore, this descriptive research was conducted to design an electronic magazine based on Augmented Reality. The development process was carried out in two stages, namely analysis and design. The analysis phase was carried out by observation using a questionnaire and the design phase was carried out by utilizing various computer software. The result of this research was an emagazine design that is integrated with Augmented Reality, so that students can see abstract biological objects by $3 \mathrm{D}$ Augmented Reality directly with the technology. These results are expected to be developed and conduct further testing
\end{abstract}

\section{Introduction}

Education is a form of embodiment of dynamic human culture and changes in the culture of life. Changes in the sense of improving education need to be made in anticipation of future interests. Educational goals can be achieved if the learning process that takes place is in accordance with the development of students so that the material received by students will be meaningful and become provisions in living their lives. A learning process is said to be good, if the learning process can generate effective learning activities. In this case it needs to be realized, the problem that determines is not the method or technique when teaching in the classroom but how students succeed in gaining understanding during the procedure (Sardiman, 2014; Andi, 2013). Advances in science and technology, especially information technology, greatly affect the preparation and implementation of learning strategies. Currently, the use of learning media among teachers, especially those based on information technology, shows a significant increase, this is in line with online learning that has been set by the ministry of

\footnotetext{
* Corresponding author.

E-mail: dekagusniaputri@gmail.com
}

Doi: https://doi.org/10.31258/jes.5.3.p.511-519 
education and culture. The use of mobile devices in learning has become a necessity in the teaching and learning process. Mobile devices such as laptops, tablets, and smartphones have become a new alternative in online learning. This technology is expected to increase pedagogical accessibility, explain abstraction information, and increase students' acquisition of science (Gafur, 2020).

Utilization of technology in the development of teaching materials can be applied in the learning process to assist students in learning biological concepts. One trend of learning media that is starting to be noticed in the world of education is media with Augmented Reality (AR) technology. According to Bitter \& Corral (2014) Augmented reality (AR) is a technology that can combine a $3 \mathrm{D}$ object into a real environment using webcam media, either through a camera on a laptop or on a mobile phone. According to Alvian (2017) AR media is good to apply in schools, based on his research showing $76 \%$ of students gave a positive response and were interested in AR learning media used by teachers during learning. Augmented Reality is a multimedia technology that can combine one or more $3 \mathrm{D}$ objects into a real environment using camera media (1qbal, 2017).

This AR integration can be innovated and developed through media or teaching materials, one of which is the development of E-magazines which include supporting learning media in the form of 3D animated markers that help students in the learning process. (Nana, 2005). An electronic magazine is an electronic version of a magazine because it is electrically based. Electronic magazines no longer use paper shoulders to write their articles like magazines in general, but in the form of digital files (Novita, 2014). E-Magazine is the electronic version of the magazine because it is electricity based. Electronic magazines are not paperbased to write various articles like magazines in general. (Nurjanah, 2014).

In addition, the implementation of this AR-based e-magazine uses a mobilephone where we know that the use of mobilephones among teenagers is very high, this is supported by data from the PPI Kominfo Research and Development Center issued in the Pocket Book and Indonesian ICT Trends (2014) the distribution of individual mobile phone users based on education level such as high school reached $89.67 \%$, SMP $77.83 \%$ in 2014 . Therefore, the use of mobile phones at the education level can be directed at utilization for learning purposes.

This AR-based e-magazine is a teaching material in which it is able to display 3D animation media of the biological object being studied. In addition, it will be even more interesting if it is used to study biological objects that are abstract or not real. Some concept in biology learning that is difficult for students to understand is the concept of the human digestive system. Digestive system material in humans is one example of biological material that studies several events related to humans themselves, such as the process of digestion of food and disorders/diseases that can occur in the digestive system. Judging from the object and its material properties, the digestive system is located in the body that cannot be observed directly, so it is relatively difficult for students to imagine it. According to Juannita (2017), the material for the human digestive system is difficult to understand. students still find it difficult to imagine how the shape and 
location of the digestive organs in the human body, Based on the above description in learning the digestive system in humans, it is very suitable to be delivered with the AR technique. human digestive system material including material that is difficult to understand. students still find it difficult to imagine how the shape and location of the digestive organs in the human body, Based on the above description in learning the digestive system in humans, it is very suitable to be delivered with the AR technique. Referring to what has been described, a research on teaching materials has been carried out, namely "Development of Augmented reality-based E-Magazines". The purpose of this study was to examine the quality of AR-based E-magazine teaching materials on human digestive system materials.

\section{Methodology}

This research was descriptive research. The e-maagzine design consisted of two stages. The first stage was the analysis stage, which was carried out using observation questionnaires to several schools and interviews with teachers. Then the second stage was the e-magazine design stage. The design of the e-maazine was done by utilizing several computer software such as photoshop, Ms. office, blender, vuforia, unity. The stages of making AR can be seen in Figure 1 (Ade, 2019).

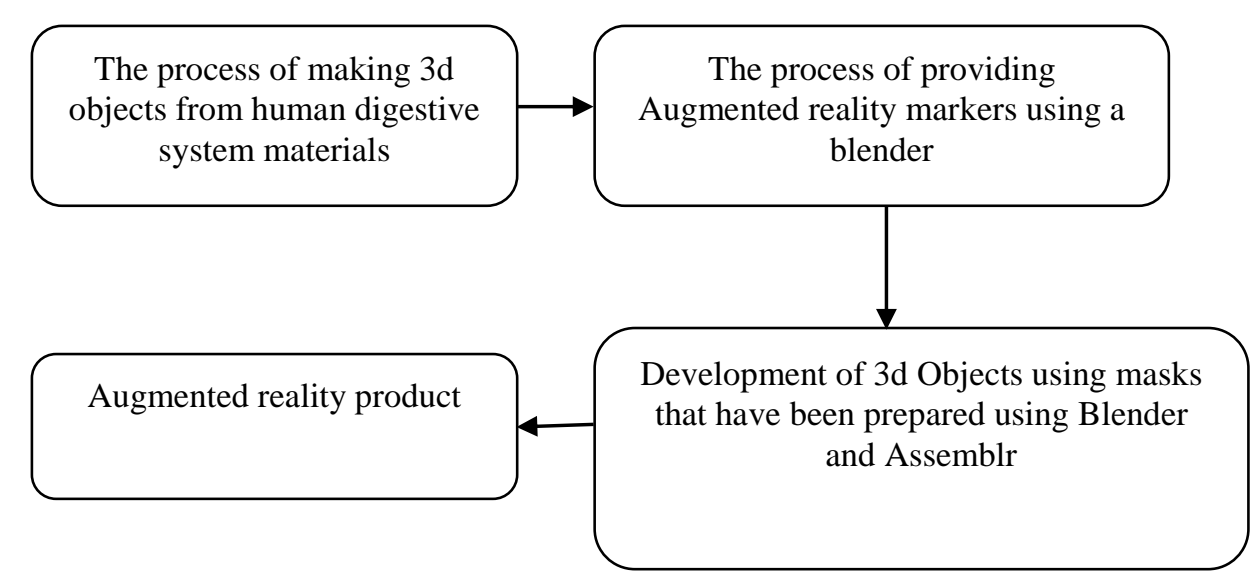

Figure 1. Design stages of making AR

\section{Results and Discussion}

The e-magazine design stage begins with conducting a curriculum analysis. First, it is known that the curriculum used in the school is the 2013 curriculum. According to Riduwan (2007), the analysis stage is an important stage in determining what should be developed and taught to students. At this stage the collection of data or information is carried out by means of observations and interviews at schools in Pangkalan Kerinci to find out information related to several aspects of the analysis. The results of observations were carried out to show the percentage of material considered difficult by students. The analysis of 
biology learning materials that are difficult for students shows that the average daily test score of the lowest students is the concept of the human digestive system, which is 65.23 , followed by the human circulatory system 76.73 plant tissue material 77.04, motion system 77.6 and cells 77.53. According to Sapuroh (2010) some concepts in biology learning are quite difficult for students to understand. One of them is an abstract concept such as the human digestive system.

\title{
Augmented Reality (AR) based e-magazine development
}

The modified e-magazine format from Suryani (2015) can be seen in Figure 2

\author{
1. Cover \\ 2. Salam redaksi \\ 3. Kompetensi dasar, Tujuan dan Indikator \\ 4. Langkah-langkah penggunaan \\ 5. Marker 1 (organ sistem pencernaan) \\ 6. Marker 2 (Struktur dan fungsi organ Mulut) \\ 7. Marker 3 (Struktur dan Fungsi organ Kerongkongan) \\ 8. Marker 4 (Struktur dan fungsi organ Lambung) \\ 9. Marker 5 (Struktur dan fungsi organ Usus Halus) \\ 10. Marker 6 (Struktur dan fungsi organ Usus Besar) \\ 11. Marker 7 (Struktur dan Fungsi organ Anus) \\ 12. Marker 8 (Proses Pencernaan Makanan) \\ 13. Marker 9 (Zat Makanan) \\ 14. Marker 10 (Penyakit yang menyerang system pencernaan) \\ 15. Profil penulis
}

Figure 2. e-magazine creation format

Along with the design of the e-magazine, a $3 \mathrm{~d}$ animation design is also carried out which will be integrated into the e-magazine through the available marker images. Furthermore, Augmented reality media was developed which will later be integrated into e-magazines to assist student learning in the material of the human digestive system. Making AR utilizes several software, such as blender, vuforia, unity, augmented reality.

The e-magazine material on the human digestive system at the first meeting (1), studied related organs in the digestive system, the structure and function of parts of the digestive system organs, the process of digestion of food, and substances in food that affect the body. In the AR-based e-magazine there are covers, steps and so on. The E-magazine Cover page is designed as attractive as possible to attract the attention of students to study the developed E-magazine. So that students become more enthusiastic in the learning process.

According to Widjajanti (2008), the display aspect is a very important aspect in the E-magazine so that students are interested and increase student interest in 
completing the tasks in the LKPD which will be given at the end of the lesson. The initial display / cover contains the title of the E-magazine as a whole, the identity column, as well as the supervisor. E-magazine cover design Previously, in e-magazines there were learning steps. Instructions for using Augmented Realitybased e-magazines contained directions/instructions for students to use the developed e-magazines. According to Prastowo (2014), the existence of instructions in the development of teaching materials aims to facilitate the use of teaching materials.

Students answer the questions in the LKPD by using the developed e-magazine. students can also be assisted by 3D Augmented Reality animation which has been added to the e-magazine. This 3-dimensional animation can also make learning more contextual (Ade, 2020). Organs in the digestive system in the developed emagazine are equipped with markers containing a $3 \mathrm{~d}$ animation database of material as an aid in finding any organs that affect the digestive system. According to Harianti (2008), using contrasting colors on important information in a medium can be better remembered by the brain. This observation section contains images that become markers of 3-dimensional animation of AR biological objects being studied. $3 \mathrm{~d}$ animation for organs in the digestive system can be seen in Figure 3.
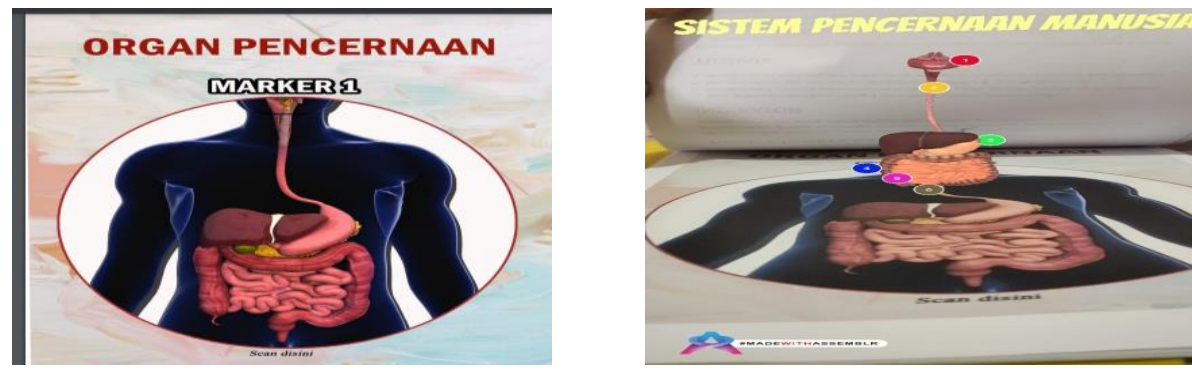

Figure 3. Animated display before using the Augmented Reality application (a), Display after using the Augmented Reality application

The organs in the human digestive system cannot be seen directly, but the developed e-magazine can illustrate that there are some digestive organs that are abstract and cannot be seen, and by using the Augmented Reality (AR) application we can observe these organs. In addition, the 3D animation that appears can show points about the organs in the digestive system in Figure 4.

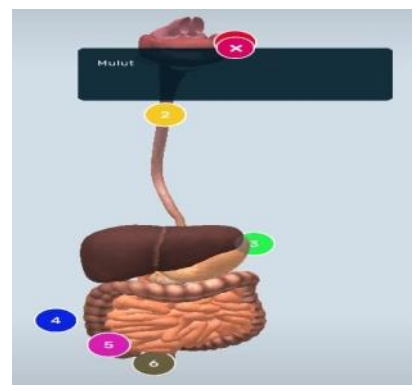

Figure 4. Display points on the organs of the digestive system. There are 6 points that have the name of each organ. 
Structure and function of the parts of the human digestive system. Each organ has a different structure, part and function. as an example is from the oral organ which has several parts such as teeth, tongue and salivary glands. In the oral cavity, chemical and mechanical digestion occurs. Mechanical is assisted by dental organs while chemical is assisted by enzymes. The various parts and functions of each of these organs are illustrated in several $3 \mathrm{~d}$ animations in the developed emagazine. The $3 \mathrm{~d}$ animation can be seen in Figure 5.
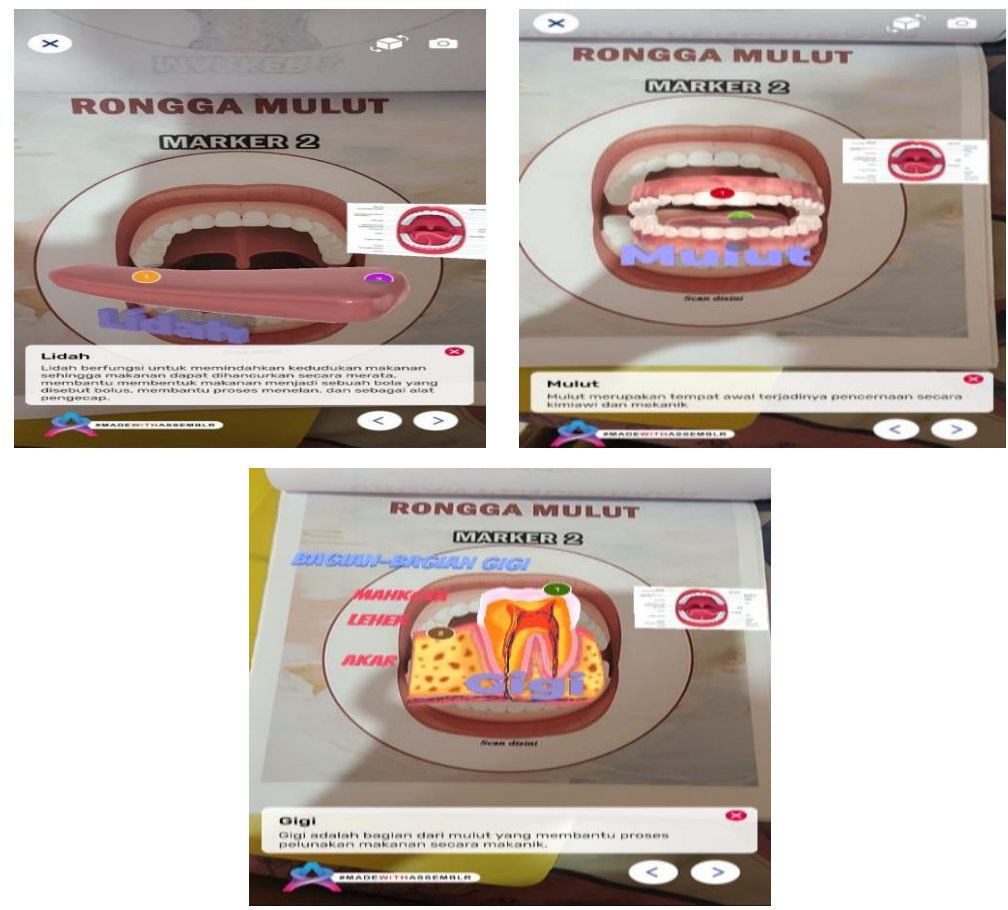

Figure 5. parts and functions of the oral organs (a), the appearance of the mucous membranes and their parts. (b) appearance of the tongue and its function. (c) appearance of dental organs, their parts and functions.

Furthermore, the parts and functions of the esophagus, stomach, small intestine, large intestine and anus. The various parts and functions of each of these organs are illustrated in several $3 \mathrm{~d}$ animations in the developed e-magazine. $3 \mathrm{~d}$ animation of each organ can be seen in Figure 6

The last indicator in this e-magazine meeting 1 is regarding the substances contained in food. There are 2 types of food substances, namely macro food substances (carbohydrates, fats, proteins, water) and micro (vitamins and minerals). Observations of food substances are presented in 1 marker containing 5 types of these substances. AR observations on developed e-magazines containing food substances can be seen in Figure 7. So with the 3d animation on Augmented Reality-based e-magazines, it can enrich students' insight regarding the concept of digestion and food substances being studied. 

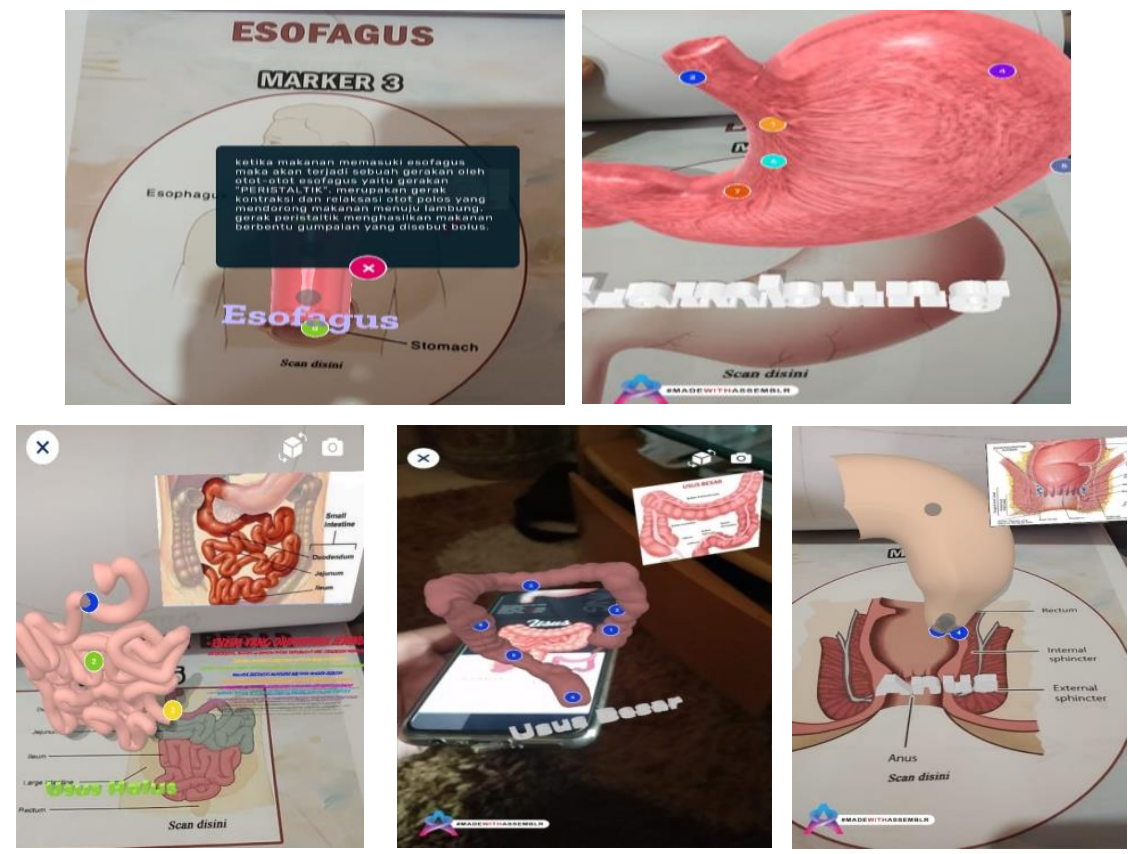

Figure 6. parts and functions of each organ (a), oesophagus organ view. (b) view of gastric organs. (c) appearance of the small intestine. (d) view of the large intestine organs. (e) view of the anal organs.
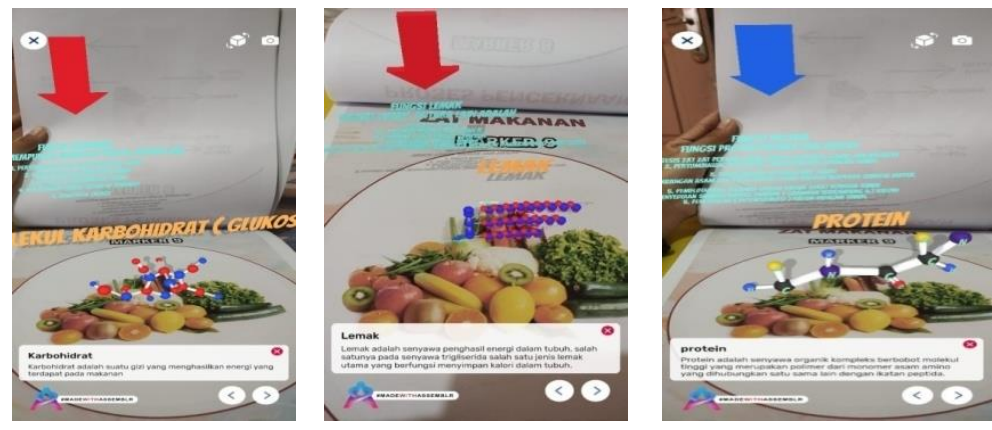

Figure 7. Molecular form of food substances and their functions

The AR-based e-magazine material on the human digestive system at the second meeting (2) has several indicators that will be studied. These indicators relate to diseases that may attack the organs of the digestive system. $3 \mathrm{~d}$ animation for diseases of the digestive system can be seen in Figure 8.

The 3d Augmented Reality animation that can be observed in the developed emagazine is an innovation that makes this e-magazine different from the usual emagazines. previous. This innovation is carried out to increase the attractiveness or interest of students to take part in learning, so that learning becomes more fun. In addition, the 3D animation can add insight and make it easier for students to find concepts and understand the concepts being studied. 

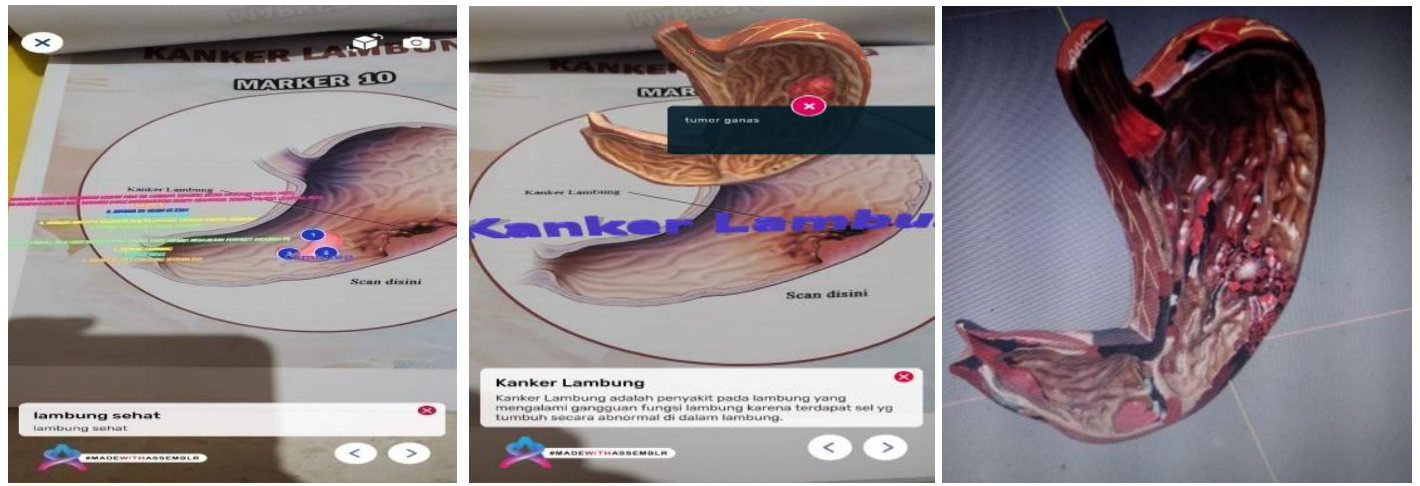

Figure 8. Diseases of the digestive system (a), AR display of a healthy stomach and its explanation (b) AR display of a sick stomach (c) display of a sick stomach 3D object

\section{Conclusion}

The result of this research is the design of an Augmented Reality (AR) based emagazine on the material of the human digestive system. The e-magazine is integrated with 3D biological objects specifically the monera concept. So students cansee directly small biological objects with technology. This research is expected to be developed and further tested to create teaching materials that are integrated with 3D augmented reality objects in biological materials.

\section{Acknowledgment}

Thank you Dr. Ir. Zulfarina, M.Si and Dr. Wan syafii, M.Si who has guided the research that has been carried out. This study was independently funded by the researcher.

\section{References}

Ade \& Zulfarina. (2020). Design of Student Worksheets Based on Augmented Reality. Journal of Educational Sciences, 4(1), 176-186.

Andi, P. (2013). Panduan Kreatif Membuat Bahan Ajar Inovatif, Diva Press, Yogyakarta.

Bitter, G., \& Corral, A. (2014). The pedagogical potential of augmented reality apps. International Journal of Engineering Science Invention, 3(10), 1317. Arizona State University, USA.

Gafur, I. A., Yustina, Y., \& Zulfarina, Z. (2020). Difficulties in the Material of Skeleton Systems and the Application of ICT in Learning Natural Sciences (IPA). Journal of Educational Sciences, 4(1), 187-199. 
Harianti, D. (2008). Metode jitu meningkatkan daya ingat (memory power). Tangga Pustaka.

Iqbal M., Hengki \& Helen. 2017. Pernerapan Augmented reality Sebagai media Pembelajaran virus dalam mata pelajaran biologi kelas X SMA. Jurnal sistem dan teknologi informasi (justin) Vol 5 No 2.

Juannita, J., \& Adhi, B. P. (2017). Pengembangan Media Pembelajaran Sistem Pencernaan Manusia Untuk Kelas 8 SMP Dengan Fitur Augmented Reality Berbasis Android (Studi Kasus: SMPN 7 Depok). PINTER: Jurnal Pendidikan Teknik Informatika dan Komputer, 1(1), 76-81.

Nana Sudjana., 2005. Penilaian Hasil Proses Belajar Mengajar. Remaja Rosdakarya. Bandung.

Nurjanah, J. R., Sukarmin, S., \& Rahardjo, D. T. (2014). Pengembangan Media Pembelajaran Interaktif E-Magazine Pada Materi Pokok Dinamika Rotasi untuk SMA Kelas XI. Jurnal Materi Dan Pembelajaran Fisika, 4(1).

Sangian, Novita. (2014). Rancang Bangun E-magazine Universitas Sam Ratulangi. Jurnal Teknik Informatika, 4(1).

Riduwan. 2007. Rumus dan Data dalam Aplikasi Statistika. Alfabeta. Bandung.

Sapuroh, S. (2010). Analisis kesulitan belajar siswa dalam memahami konsep biologi pada konsep monera di Man Serpong Tangerang. Jurusan Pendidikan IPA. Fakultas Ilmu Tarbiyah dan Keguruan. UIN Syarif Hidayatullah. Jakarta.

Sardiman, A. M. (2014). Interaksi dan Motivasi Belajar Mengajar, Rajawali, Jakarta.

Suryani, L. (2015). Improving students reading skills by using the mind map technique at SMAN1 Kretek in the academic year of 2013/2014. Yogyakarta: State University of Yogyakarta.

Widajanti, E. (2008). Peran Teknologi Informasi Untuk Mencapai Keunggulan Kompetitif. Fakultas Ekonomi Universitas Slamet Riyadi Surakarta.

How to cite this article:

Putri, D. G., Zulfarina., \& Syafii, W. (2021). Development of Augmented Reality-Based E-Magazine. Journal of Educational Sciences, 5(3), 511-519. 